\title{
UM ESTUDO DE CASO SOBRE AS PERCEPÇÕES DA PROFESSORA SUPERVISORA E SEU ESTAGIÁRIO NO PERÍODO DO ESTÁGIO CURRICULAR SUPERVISIONADO
}

\section{ARTIGO ORIGINAL}

LIMA, Diane $\mathrm{Mota}^{1}$, COSTA, Miguel Ataíde Pinto $\mathrm{da}^{2}$, SANTOS, José Henrique dos ${ }^{3}$

\begin{abstract}
${ }^{1}$ Mestra pelo Programa de Mestrado Profissional em rede de Educação Física pela UNESP-Presidente Prudente/SP(2020).Professora pesquisadora do Grupo Pesquisa em Pedagogia da Educação Física e do Esporte (GPPEFE-2016), no Departamento de Educação Física, UFRRJ. Professora Especialista em Dança e Consciência Corporal pela Universidade Gama Filho (2013). Professora efetiva do Município do Rio de Janeiro (SME-RJ-2010) e do Governo do Estado do Rio de Janeiro (SEEDUC-RJ-2010). Graduada em Licenciatura Plena em Educação Física pela Universidade Federal Rural do Rio de Janeiro - UFRRJ (2008).

${ }^{2}$ Orientador. Doutor e Mestre em Epidemiologia em Saúde Pública pela Escola Nacional de Saúde Pública Sérgio Arouca - Fiocruz. Possui graduação em Licenciatura em Educação Fisica pela Universidade Federal Rural do Rio de Janeiro (2007). Tem experiência na área de Psicologia Educacional, com ênfase em Psicologia do Ensino e da Aprendizagem, área onde tem especialização concluída na mesma Universidade. Atualmente trabalha como professor de Educação Física do Colégio Pedro II.

${ }^{3}$ Orientador. Possui graduação em Licenciatura Plena Em Educação Física pela Universidade Federal Rural do Rio de Janeiro (1983), Mestrado em Ciências da Motricidade Humana pela Universidade Castelo Branco (1996) e doutorado em Ciências da Educação - Motricidade Humana pela Faculdade de Motricidade Humana - Universidade Técnica de Lisboa (2004). Atualmente é professor Associado III da Universidade Federal Rural do Rio de Janeiro. Tem experiência nas áreas de Educação e Educação Física Escolar, com ênfase na Formação profissional, estágio curricular supervisionado, análise do processo ensinoaprendizagem, Motivação na educação Física Escolar, atualmente atuando principalmente nos seguintes temas: formação profissional e continuada em Educação Física, Estágio Currilular Supervisionado e Motivação na educação física escolar. É líder do Grupo de Pesquisa em Pedagogia de Educação Física e Esporte,
\end{abstract}

RC: 88720

Disponível em: $\quad$ https://www.nucleodoconhecimento.com.br/educacao/percepcoes-da- 
LIMA, Diane Mota. COSTA, Miguel Ataíde Pinto da. SANTOS, José Henrique dos. Um estudo de caso sobre as percepções da professora supervisora e seu estagiário no período do estágio curricular supervisionado. Revista Científica Multidisciplinar Núcleo do Conhecimento. Ano 06, Ed. 06, Vol. 10, pp. 30-49. Junho de 2021. ISSN: 2448-0959, Link de

acesso: https://www.nucleodoconhecimento.com.br/educacao/percepcoes-da-

professora, DOI: 10.32749/nucleodoconhecimento.com.br/educacao/percepcoes-daprofessora

\section{RESUMO}

O objetivo desse estudo foi analisar de forma comparativa as percepções da Professora Supervisora (PS) e de seu Estagiário sobre o período de Estágio Curricular Supervisionado no ambiente escolar. A pesquisa se definiu pelo método qualitativo, um estudo de caso, sob a perspectiva do modelo analítico descritivo. Os participantes foram uma Professora Supervisora de Educação Física da rede básica de ensino e seu estagiário de Educação Física. Os instrumentos adotados foram Notas de Campo, Entrevistas Semi-Estruturadas e Documento do Relatório Final do Estagiário, e foram submetidos à técnica de Análise de Conteúdo. Os resultados dessa análise pontuaram que a percepção de ambos sobre o período de estágio supervisionado foi bem similar. Essa pesquisa compreende como fundamental que os ambos entendam a importância do estágio, construam uma relação de parceria e consciência dos papéis que representam.

Coordenador do Programa de Pós-graduação em Educação, Contextos Contemporâneos e Demandas Populares da UFRRJ (PPGEDUC), Coordenador das atividades de Estágio Supervisionado do Curso de Educação Física da UFRRJ e Coordenador do PIBID Educação Física UFRRJ/CAPES.

RC: 88720

Disponível em: https://www.nucleodoconhecimento.com.br/educacao/percepcoes-daprofessora 
Palavras-Chave: Formação de professores, Estágio curricular supervisionado, Educação Física.

\section{INTRODUÇÃO}

O conceito de "estágio" vincula a ideia de prática em um ambiente conveniente e com a supervisão e orientação de outro profissional do ramo. Com uma característica prática, o estágio está em vários locais de treinamento profissional (escolas, hospitais, indústrias etc.) com o objetivo de oportunizar vivências do estagiário com seu futuro ambiente profissional.

Ao longo da história, o estágio curricular supervisionado na formação de professores foi considerado como a parte prática do curso de licenciatura, com a intenção de adquirir o conhecimento técnico sob a forma de imitação de modelos, sob o pressuposto de que a "realidade do ensino" e "os alunos são imutáveis" (PIMENTA; LIMA, 2011, p. 35). Nessa perspectiva, se deixa de considerar as mudanças e avanços sociais importantes da sociedade e limita a ação do estagiário na escola a um observador das aulas e futuramente um imitador dos modelos de aula, sem qualquer reflexão crítica do ambiente observado.

"Deve promover a articulação entre a formação inicial e a prática, integrando o processo de formação docente com o campo de atuação, não somente enquanto objeto de análise e de investigação, mas também como objeto de interpretação crítica" (PIMENTA; LIMA, 2011, p. 24).

O período de estágio também é visto como uma atividade de pesquisa, pois o graduando poderá considerar as orientações oriundas das universidades para fomentar suas atitudes e reflexões na prática docente cotidiana (VEDOVATTO IZA; SOUZA NETO, 2015). Essa perspectiva de estágio coloca a universidade e a escola

RC: 88720

Disponível em: $\quad$ https://www.nucleodoconhecimento.com.br/educacao/percepcoes-daprofessora 
como importantes espaços de formação docente, trabalhando em parceria para uma formação docente coerente com a realidade de ser professor

A Lei do estágio № 11.788, de 25 de setembro de 2008, esclarece em seu parágrafo primeiro, do artigo $3^{\circ}$, a necessidade de o estagiário possuir uma orientação advinda da universidade por seu "professor orientador" responsável pela atividade curricular estágio, e um "professor supervisor" na escola para continuar e ampliar as orientações na prática pedagógica.

$\S 1$ 을 estágio, como ato educativo escolar supervisionado, deverá ter acompanhamento efetivo pelo professor orientador da instituição de ensino e por supervisor da parte concedente, comprovado por vistos nos relatórios referidos no inciso IV do caput do art. 7으 desta Lei e por menção de aprovação final.

Para Benites (2012), o professor supervisor não é devidamente contemplado na legislação que regulamenta o estágio supervisionado e seu funcionamento, não esclarecendo o verdadeiro papel do professor supervisor com o estagiário. $\mathrm{O}$ professor supervisor ainda sofre com a carência na sua formação profissional para orientar e formar um outro futuro colega de trabalho, o que resulta, muitas vezes, em estágio supervisionados sendo realizados de forma "artesanal", sem a devida sistematização pelos professores supervisores.

Sobre essa demanda do professor supervisor ao receber o estagiário sem a devida formação para tal, a professora Sarti (2009) pontua que os "professores em exercício são chamados a desempenhar o papel de iniciadores de uma nova geração docente" (p. 134).

\section{CONTEXTO DA PESQUISA}

Para que o período do estágio supervisionado cumpra com seus objetivos básicos de formação e antecipação da realidade ao licenciando, todos os envolvidos devem

RC: 88720

Disponível em: https://www.nucleodoconhecimento.com.br/educacao/percepcoes-daprofessora 
exercer seus papéis de participantes e formadores. O professor supervisor deve assumir o destaque na recepção e orientação do estagiário nas suas aulas durante todo o período do estágio.

Essa pesquisa objetivou entender quais as percepções que a professora supervisora e seu estagiário construíram sobre o período de estágio realizado na escola?

Uma análise comparativa sobre como os participantes entenderam esse processo de estágio se faz necessário para uma análise reflexiva do estágio curricular supervisionado.

\section{CAMINHOS METODOLÓGICOS}

Os métodos adotados para esse estudo de caso foram o qualitativo, documental, sob Modelo Analítico Descritivo. Os instrumentos requeridos foram entrevista semiestruturadas (no início e no final), Notas de Campo e Documento Relatório Final do Estagiário.

Os participantes formaram a Professora Supervisora Bernardete de Educação Física da rede básica de ensino e seu estagiário Bruno (nomes não verdadeiros), aluno do curso de licenciatura em Educação Física.

A pesquisa foi realizada na escola dos participantes, sendo as visitas agendadas e acordadas por todos. Estas visitas foram no total de cinco dias, no período vespertino, totalizando $25 \mathrm{~h}$.

Após o período de coleta, os dados foram transcritos e analisados com a técnica de Análise de Conteúdos (BARDIN, 1977).

Nessa pesquisa emergiram as Categorias de Indicadores, que são condutas que o professor supervisor adota com seu estagiário durante o estágio curricular

RC: 88720

Disponível em: $\quad$ https://www.nucleodoconhecimento.com.br/educacao/percepcoes-daprofessora 
supervisionado. São eles: Chegada, Apresentação de Instrumentos Pedagógicos (escola/professor), Disponibilidade de Comunicação e Demonstração de Interesse na Formação do Estagiário, Expectativas com o Estagiário, Participação do Estagiário, Socialização Profissional do Estagiário, Orientação e Feedback, Relacionamento entre PS e Estagiário e Reflexão sobre a Prática e Carreira Docente.

\section{RESULTADOS E DISCUSSÕES}

\subsection{CHEGADA DO ESTAGIÁRIO}

\section{Percepção do Estágio Supervisionado do Professora Supervisora Bernardete}

Sobre o estágio supervisionado, a professora comentou que ao receber um estagiário para orientar, pergunta sobre as principais dúvidas que ele possui e, de imediato, apresenta-Ihe a realidade e a rotina da escola: "Bom, pergunto ao estagiário as dúvidas principais que ele tem e falo realidade, o que acontece, eles vêm como muita dúvida, né? Mostramos tudo. Apresento, falo como que é a rotina" (Entrevista Inicial).

A docente ainda comentou que a escola tem grande satisfação em receber estagiários e que "são (os estagiários) muito bem recebidos" em um ambiente "bastante harmonioso".

A PS comentou que o estagiário Bruno foi bem recebido na escola pela equipe de gestão e que a rotina realizada com o estagiário Bruno foi pautada nos conceitos da "assiduidade, domínio de turma, relação entre estagiário e alunos e proatividade" (Entrevista Final).

\section{Percepção do Estágio Supervisionado da Estagiário Bruno}

Sobre a sua recepção, o estagiário Bruno disse que foi muito bem acolhido pela direção e pelos funcionários da escola:

RC: 88720

Disponível em: https://www.nucleodoconhecimento.com.br/educacao/percepcoes-daprofessora 
Bom, nos primeiros dias que eu procurei o colégio, eu fui super bem recebido pela coordenadora... logo ela me encaminhou pro diretor, que no momento não pode me atender porque ele tava (estava) com pais, aí eu aguardei um pouco... e o diretor foi super receptivo, me mostrou os horários dos professores que tinham, de Educação Física, no colégio, e falou que eu poderia ficar a vontade pra voltar, o dia que eu quisesse, me deu o horário da escola também, tudo direitinho para que eu pudesse resolver a documentação, né! Eu fui bem aceito de cara assim. As pessoas foram super receptivas e simpáticas (Entrevista Inicial).

Sobre as questões de organização e disponibilidade de horários para realizar o estágio.

Então, é... eles (equipe pedagógica) me deram... uma vasta lista de professores. Eu acho que são/eram quatro ou cinco professores, e eu... pude ter a liberdade de escolher o horário que... que ficaria melhor pra mim. É...eu botei como prioridade também as minhas aulas aqui na universidade... porque... eu jamais deixaria de vir pra alguma disciplina pra fazer o estágio. E... como eu já tinha me preparado mais ou menos pra... pra disciplina estágio... eu já tinha deixado alguns espaços na grade que eu imaginava é... que conseguiria um colégio, entendeu? Eles (equipe pedagógica) não interferiram de nenhuma forma, me deixaram com toda liberdade possível e eu disse meus horários pra eles, eles falaram que tudo bem, tranquilo... que eu puder... eu vou... às vezes se eu precisar sair cedo e comunicar com a professora, a professora é supertranquila também, ela não... reclama, não fala nada disso. E... é tranquilo... com relação a horário eu sou bem tranquilo (Entrevista Inicial).

estagiário Bruno comentou que a professora supervisora Bernardete apresentou comprometimento profissional e que o recebeu muito bem nas suas aulas:

Meu professor supervisor foi a professora Bernardete, uma excelente profissional que faz o que ama, e meu encontro com ela foi muito legal porque ela me recebeu super bem e a primeira coisa que ela fez foi mostrar tudo que a gente tinha, como que funcionava o colégio, né, os projetos (Entrevista Inicial).

As condições estruturais e de organização da escola foram apresentadas pelo estagiário Bruno com um dos problemas que ele teve que enfrentar. A quadra pequena, a necessidade de dividi-la com outro professor e a quantidade de alunos

RC: 88720

Disponível em: $\quad$ https://www.nucleodoconhecimento.com.br/educacao/percepcoes-da- 
foram alguns pontos levantados por ele: "Era bem complicado, porque eram cerca de 50 crianças num espaço muito limitado e dar conta de observar uma grande quantidade de crianças executando os fundamentos e corrigi-las ao mesmo tempo" (Relatório Final).

O estagiário relatou sobre sua boa recepção e reconheceu que diante das adversidades, a sua presença na escola $\mathrm{B}$ era também de grande ajuda à professora Bernadete.

Ela me recebeu muito bem... me recebeu muito bem (tom de satisfação) porque ela é uma pessoa simpática, uma pessoa parceira e também porque a condição lá que a gente tem que dar aula no estágio é... tipo... é uma coisa louca porque é uma quadra pequena, dividida ao meio e são duas turmas de 40 alunos, então, imagina... cada metade com 40 alunos. Então, ela pode, tipo assim, ficar muito feliz com a minha chegada porque eu de certa forma eu ajudo ela a administrar (tom de satisfação) toda essa turma, assim, ela fica... bem tranquila... ela sempre me tratou muito bem (Entrevista Final).

\subsection{APRESENTAÇÃO DE INSTRUMENTOS PEDAGÓGICOS (ESCOLA/PROFESSOR)}

\section{Percepção do Estágio Supervisionado do Professor Supervisor Alan}

A situação da disposição do espaço físico e a escassez de material específico para as aulas de Educação Física foi bastante recordada pela professora Bernardete, porém a mesma afirmou que isso não prejudicou o estágio. "Em momento nenhum, pois sempre enfrentamos tudo com muita paciência, dinamismo e atenção. E ainda acrescentou que foi bom para o estagiário ter esse contato com a realidade das escolas públicas do município (Entrevista Final).

\section{Percepção do Estágio Supervisionado da Estagiária Alice}

RC: 88720

Disponível em: $\quad$ https://www.nucleodoconhecimento.com.br/educacao/percepcoes-da- 
Sobre o planejamento e a identidade da escola, o estagiário afirmou que após ter confirmado sua participação e continuidade no estágio, a PS disponibilizou o planejamento anual organizado pela Secretaria Municipal de Educação e o Projeto Político Pedagógico da escola para utilizar na orientação.

O planejamento que fazia, segundo o estagiário, traduzia-se em algumas "ideias" que ele apresentava a professora e "explicava mais ou menos antes das aulas" e ela decidia se eram possíveis ou não. Em caso negativo, a professora explicava o motivo e, através do diálogo, PS e estagiário buscavam aprimorar essas ideias para serem aplicadas em outra oportunidade. Os conteúdos ministrados nas intervenções com a professora supervisora, por sua vez, eram os pré-estabelecidos no planejamento anual recebido do município e adequados à realidade da Escola $\mathrm{B}$.

É um calendário bimestral que a gente seguia, na medida do possível, por conta da falta de materiais e também pelo espaço, que era escasso. A quadra era pequena, com duas turmas de 50 alunos. Então a gente trabalhava e tentava se aproximar ao máximo do conteúdo bimestral (Entrevista Final).

\subsection{DISPONIBILIDADE DE COMUNICAÇÃO E DEMONSTRAÇÃO DE INTERESSE DO PS NA FORMAÇÃO DO ESTAGIÁRIO}

\section{Percepção do Estágio Supervisionado do Professor Supervisor Alan}

Quando perguntada sobre como concebia sua função junto ao estagiário nesse processo de formação que estava iniciando, a professora relatou ter o "papel principal", pois ao se espelhar nela, o estagiário poderá "ser melhor no futuro". E sobre as suas expectativas com esse estágio, afirmou: "Eu espero que esse profissional no futuro seja o melhor possível, assim como eu passei por todos os estágios e fui uma boa profissional. A professora Bernardete manifestou ainda a expectativa de assumir a função de um modelo a ser seguido pelo estagiário, ao considerar que as palavras

RC: 88720

Disponível em: https://www.nucleodoconhecimento.com.br/educacao/percepcoes-daprofessora 
a seguir poderiam partir dele: "Eu quero ser igual e ela... poxa... (risos)" (Entrevista Inicial).

A docente Bernardete acredita que exerce um importante papel no processo de formação profissional do estagiário: "Essa é a minha maior preocupação em contribuir na formação de futuros colegas de trabalho e me preocupo em prestar o melhor durante essa passagem de meu estagiário". E relatou se sentir capaz para tal, mas ainda ter dúvidas sobre o processo de orientação do estagiário. "Eu me sinto capaz, porém com dúvidas em relação por onde começar de qual ponto de partida. $\mathrm{Na}$ verdade, não tenho a receita do bolo, porém sei que juntos iremos compartilhar dúvidas, sugestões e criarmos um ambiente facilitador". A PS ainda acrescentou que acredita seja necessária uma capacitação específica para o professor supervisor para que este oriente outros futuros colegas de trabalho de forma verdadeiramente profícua: "Percebo sim o quanto é importante de verdade ter esse conhecimento (formação específica) (Entrevista Final).

\section{Percepção do Estágio Supervisionado da Estagiária Alice}

\subsection{EXPECTATIVAS DO PS COM O ESTAGIÁRIO}

\section{Percepção do Estágio Supervisionado do Professor Supervisor Alan}

Ela acrescentou que, ao receber o estagiário em suas aulas, espera o apoio e iniciativa do estagiário junto as tarefas e atividades escolares: "Eu espero proatividade, que ele me ajude, que ele tenha essa proatividade, essa inciativa".

Sobre a rotina que pretende adotar com o estagiário Bruno, a professora esclareceu que "Minha rotina é mostrar toda a escola e a preocupação de entender o que o estagiário precisa para seu entendimento enquanto futuro profissional (Entrevista Inicial).

RC: 88720

Disponível em: https://www.nucleodoconhecimento.com.br/educacao/percepcoes-daprofessora 
Sobre as questões relacionadas ao aprendizado do estagiário, a professora supervisora Bernardete comentou que o estagiário precisa aprender ao longo do processo de estágio "principalmente a questão dos objetivos, dos conteúdos" e ainda, "as principais dificuldades que ele sente. Eu pergunto logo, primeiramente, quais as dificuldades que você tem? Você já vivenciou esse ambiente escolar?". E afirmou que na escola, o estagiário tem condições de vislumbrar e desenvolver esses conhecimentos. Destacou também, que o estagiário deve aprender diversas questões da escola. "Para ser um bom profissional no futuro, você tem que estar atento a várias questões, psicológicas, afetiva, cognitiva... tudo isso". E quando perguntada sobre o que mais o estagiário poderia aprender com ela, afirmou: "A responsabilidade... ta lidando com vidas, né?! Tem que estar atento a isso" (Entrevista Inicial).

\section{Percepção do Estágio Supervisionado da Estagiária Alice}

O estagiário Bruno comentou ter boas expectativas com o atual estágio e que devido à boa recepção que teve, mudou a sua opinião sobre a escola e que pretendia fazer os outros módulos do estágio na escola:

Nesse período de estágio, eu pretendo continuar aprendendo muito mais e período que vem eu quero puxar outro estágio porque eu tô (estou) gostando muito do ambiente escolar. Como é uma das áreas que eu pretendo seguir, eu pretendo continuar fazendo estágio e se tudo der certo, eu pretendo fazer parte do município de XXX (sigilo de pesquisa). Como eu sou morador daqui, sou aluno e morador também, eu tô (estou) gostando muito do ambiente, foi uma surpresa boa pra mim, né, que eu tinha uma visão formada muito ruim sobre o município e eu tava (estava) completamente enganado. Isso foi uma coisa muito feliz pra mim. (Entrevista Inicial).

\subsection{PARTICIPAÇÃO DO ESTAGIÁRIO NO COTIDIANO ESCOLAR}

\section{Percepção do Estágio Supervisionado do Professor Supervisor Alan}

RC: 88720

Disponível em: $\quad$ https://www.nucleodoconhecimento.com.br/educacao/percepcoes-da- 
A professora supervisora Bernadete comentou que sempre permitiu que o estagiário Bruno fizesse intervenções nas aulas, onde desenvolveram um trabalho de parceria mútua. Sobre esses momentos de intervenção, disse que: "O estagiário foi muito bem em seu desenvolvimento durante as aulas e não houve qualquer interrupção de minha parte durante o decorrer da aula. Também costumo dar o feedback após a aula até para não falar na frente da turma". A professora acrescentou que os conteúdos das aulas dadas pelo estagiário estavam de acordo com as diretrizes do planejamento anual realizado pelo grupo de docentes de Educação Física do município, apresentado ao estagiário no início do estágio. "O estagiário estava sempre interessado e mostrou-se bastante engajado nos conteúdos propostos. Bruno sempre esteve disposto e proativo com novas possibilidades". (Entrevista Final).

\section{Percepção do Estágio Supervisionado da Estagiária Alice}

O estagiário Bruno relatou que as atividades pedagógicas destinadas a ele eram todas direcionadas a área de Educação Física assim como recebeu a orientação de estágio por uma professora licenciada em Educação Física.

Segundo o estagiário Bruno, as tarefas não eram diretamente designadas a ele, pois sempre conversavam e as decidiam juntos, sem nenhuma autoridade ou voz de comando sob o estagiário.

A professora Bernardete, na verdade, ela não designava nada para mim, era tudo em conjunto. A gente conversa, ela me dava liberdade de ter a posição realmente de professor, então, a gente conversava e via o que seria o melhor para fazer para mim, para ela e para turma. Era um pensamento conjunto, ela não dava esse tom de autoridade, de impor. Ela gostava de conversar comigo para ver minha desenvoltura com relação a criatividade também, além da desenvoltura com relação a didática (Entrevista Final).

Sobre esses momentos de intervenção, o estagiário Bruno acredita que

RC: 88720

Disponível em: https://www.nucleodoconhecimento.com.br/educacao/percepcoes-daprofessora 
ter a experiência na prática como a dominância da turma e de um conteúdo para com o professor e o colégio também. Tendo noção de tudo que está acontecendo, planejando a aula e correndo atrás dos objetivos que essa aula tem como conquistar (Entrevista Final).

O estagiário esclareceu que no início do período de estágio passou pelos momentos de observação das aulas e que, após a PS passar os conteúdos, deixava-o livre para ministrar as aulas. O estagiário teve permissão da professora para dar aulas e, na sua opinião, foi bastante apoiado e assistido nesses momentos de intervenção.

Bom, na maioria das aulas eu dei aula junto com a professora. Eu pude ser protagonista junto com a professora. Ela me confiou muito, ela nas primeiras aulas viu que eu tinha meio que um pulso firme ao saber lidar com as crianças, então...ela meio que deixou eu fluir a aula com ela e só foi me dando uns toques, na verdade, coisas que eu podia melhorar, mais dicas assim para malícia propriamente dito de professor. Coisas que só quem dá aula a bastante tempo já entende (Entrevista Final).

\subsection{SOCIALIZAÇÃO PROFISSIONAL DO ESTAGIÁRIO}

\section{Percepção do Estágio Supervisionado do Professor Supervisor Alan}

Sobre a socialização profissional do estagiário no ambiente da escola, a professora comentou que foi "uma relação de companheirismo, cordial e educada" e a relação com os alunos foi "baseada no respeito mútuo e com muito carinho, respeito e diálogo". De acordo com a PS, os espaços mais frequentados pelo estagiário foram às salas de aula e a quadra esportiva, sendo que o estagiário Bruno também foi apresentado aos outros espaços físicos da escola no dia de seu acolhimento. Ainda sobre a socialização profissional do estagiário Bruno, a professora Bernardete afirmou que: "Ele é bastante comunicativo e muito bem relacionado no ambiente (escolar)" (Entrevista Final).

\section{Percepção do Estágio Supervisionado da Estagiária Alice}

RC: 88720

Disponível em: $\quad$ https://www.nucleodoconhecimento.com.br/educacao/percepcoes-daprofessora 
E ainda, que a PS orientou e apresentou o estagiário ao espaço físico, aos materiais disponíveis e aos outros agentes de educação da Escola B: "Eu fui apresentado devidamente a todos, inclusive aos inspetores também, o pessoal da limpeza. Lá é um colégio muito legal, é como se fosse uma espécie de família lá. Todo mundo se conhece muito bem, todo mundo se dá muito bem" (Entrevista Inicial).

O estagiário ainda explicou sobre o seu relacionamento com as outras pessoas dentro da escola e afirmou que foi tratado muito bem pelos outros professores e que muitas vezes foi chamado pelo nome, o que Ihe foi motivo de surpresa positiva:

Eu tive uma relação muito legal, todo mundo sorria para mim, todo
mundo me tratava super bem. A gente buscava os alunos na sala,
como o colégio lá é fundamental, só para fazer Educação Física que
eles mudavam de sala, então a gente buscava os alunos nas salas
para descer para o pátio. E eu tinha contato com alguns professores,
me tratavam bem, guardavam meu nome, que por incrível que pareça
isso é uma coisa legal, porque a maioria não lembra do nome. E toda
vez que eu ia embora ou chegava era bem recebido. E como eram
pessoas que a maioria morava em XXX (sigilo de pesquisa) mesmo,
sempre tinha um assunto ou outro que a gente falava. Fui tratado com
uma certa simpatia (Entrevista Final). estagiário disse que não teve contato com todos os professores da escola, mas aqueles que o conheceram, aparentavam ser pessoas maravilhosas e pareciam estar felizes no que faziam: "Eles orientavam, tratavam bem as crianças e eram organizados quanto a tudo". Os gestores da escola também o receberam muito bem e o ajudaram a encontrar o "melhor professor" de acordo com o horário disponível, mostraram a escola, os materiais, o apresentaram para os funcionários e passaram os horários. Os funcionários, na opinião do estagiário, eram "muito educados e preparados", pois toda vez que tinha um problema, o mesmo era solucionado com eficácia. Sobre os pais e demais responsáveis, o estagiário pontuou que não teve muito contato, porque os mesmos só apareciam no horário de entrada e saída dos alunos. Não teve oportunidade, também, de prestigiar uma reunião de pais, o "que seria de extrema importância porque e algo que vou lidar diretamente após a formação". Ele ainda RC: 88720

Disponível em: $\quad$ https://www.nucleodoconhecimento.com.br/educacao/percepcoes-daprofessora 
acrescentou que a Educação Física era bem-vista e associada com as outras disciplinas desde a hora de buscar ou levar os alunos em sala até os eventos de datas comemorativas na escola (Relatório Final).

Sobre o relacionamento com os alunos, o estagiário Bruno esclareceu que foi muito bom e que a professora Bernadete foi fundamental para isso, pois o apresentou para turma como professor:

Meu relacionamento com os alunos era o melhor possível, eles me adoravam pelo fato de eu ser professor de futebol também. Isso chamava muito atenção deles e também, a Fernanda me apresentou de uma forma muito legal, positiva, me apresentou até como professor, né?!(risos)...falou que: "Ele vai ficar com a gente e tal...". Falou que eu ia ficar com eles durante um período e, aí, todas as crianças se animavam, foi uma coisa muito divertida, muito legal a forma que eles me abraçavam (Entrevista Final).

Dentre os vários espaços escolares, o estagiário comentou que o que mais frequentou e se sentiu mais à vontade foi à quadra, mas que foi bem tratado em todos os outros lugares da escola:

O espaço que me senti mais a vontade foi a quadra porque um futuro profissional de Educação Física, é uma coisa que eu amo. Mas em todos os ambientes da escola eu me sentia muito abraçado, eles me ofereciam café da tarde, almoço e na portaria eu era muito bem recebido, todo mundo sorria para mim, me tratava bem, era simpático comigo. Então, eu não tenho nada que reclamar com relação as pessoas e a socialização naquele ambiente. Acho que o diretor de lá faz uma gestão maravilhosa e proporciona esse ambiente no colégio (Entrevista Final).

\subsection{ORIENTAÇÃO E FEEDBACKS}

\section{Percepção do Estágio Supervisionado do Professor Supervisor Alan}

RC: 88720

Disponível em: $\quad$ https://www.nucleodoconhecimento.com.br/educacao/percepcoes-da- 
A professora comentou que o estagiário sempre demonstrou boa receptividade às intervenções dela e apresentou um comportamento muito proativo nas aulas: "Sempre. Em uma das aulas sobre futebol para deficientes visuais o estagiário disponibilizou seu tempo para procurar o material para a aula prática. O Bruno é muito tranquilo e sempre disposto a ajudar". Em situações de feedback da orientação, a professora declarou que o estagiário "sempre foi bem crítico e bastante interessado mostrando suas opiniões, questionamentos e soluções para as necessidades surgidas" (Entrevista Final).

Quando perguntada sobre a avaliação do período de estágio do Bruno, a professora comentou que a atuação dele foi "excelente, muito bem orientada e executada. Tudo correu de forma tranquila dentro da normalidade e os alunos participaram com muito divertimento e motivados com as brincadeiras, jogos e brinquedos". A professora supervisora acrescentou que não houve necessidade de qualquer correção por comportamentos inadequados do estagiário e que ele apresenta "domínio de turma, dinamismo na hora de exposição das atividades, relação com a turma, proatividade e respeito". Porém, a PS destacou que precisou orientar o estagiário no que diz respeito à pontualidade e ao cumprimento dos horários. "O que conversei com o Bruno em relação a isso foi à questão do cumprimento do horário. Apenas mostrei a questão da importância em chegar no horário quando ele estiver empregado em uma instituição". (Entrevista Final).

\section{Percepção do Estágio Supervisionado da Estagiária Alice}

O estagiário Bruno acrescentou que após alguns feedbacks para ajustes, o professor supervisor e ele começaram a atuar juntos e que ele recebeu, também, importantes avaliações da professora Bernadete desde o início do período de estágio para melhorar sua conduta em aula. "Houve sim (avaliações), nas primeiras aulas ela me deixou mais livre para poder me observar e logo depois ela me deu o feedback para

RC: 88720

Disponível em: https://www.nucleodoconhecimento.com.br/educacao/percepcoes-daprofessora 
eu poder melhorar em algumas situações e me deu alguns toques com relação as turmas" (Entrevista Final). E ainda sobre esses momentos de feedback que recebia da professora Bernadete, o estagiário destacou as principais falas manifestadas por ele:

Diversas aulas, algumas coisas que eu poderia ter melhorado, ela deixava rolar e logo após ela falava comigo: "Ó...esse aluno aqui é melhor você falar dessa forma porque a personalidade dele é essa, entendeu? Com essa menina aqui, você já pode falar igual você fala com esse menino, tem que ter mais pulso firme, e tal...entendeu?" Eram mais dicas com relação aos alunos e também, com o controle da turma porque imagina uma quadra $40 \times 20 \mathrm{~m}$ para 100 crianças, né? correndo desenfreadamente. Então, recebi algumas dicas de como ter um controle melhor, não total, porque é quase impossível, mas um controle melhor com relação a turma (Entrevista Final).

O estagiário relatou que quando chegava à escola, a aula já tinha começado e devido à necessidade de apoio, aparentemente, a professora supervisora Bernadete se interessava mais que ele aprendesse as dinâmicas e técnicas de como dar aula e controlar os alunos na atividade. Mas destacou que a professora, sempre que tinha oportunidade fora da quadra, conversava sobre a vida docente no seu dia a dia.

Bom, eu acho que como eu chegava basicamente no horário que estava acontecendo a aula, o objetivo principal (da professora) era que eu aprendesse a maneira certa de dar aula e controlasse os alunos. Mas sempre que nós tínhamos um momento fora da quadra, fora da sala de aula, ela tentava me mostrar tudo que ela podia sobre como funcionava a docência no dia a dia. Ela me mostrou provas e trabalhos que ela passava, me apresentou toda a equipe da secretaria, me convidava para as reuniões, me mostrava todo o planejamento que tinha. Então, eu acredito que eu tenha aprendido também muito mais a dar aula em si e a controlar os alunos naquela situação. Porque foi uma coisa que eu tive muito mais contato do que com as dificuldades do dia a dia docente, porque eram alguns dias da semana só e não tinha como ter noção de tudo (Entrevista Final).

\subsection{RELACIONAMENTO ENTRE PROFESSOR SUPERVISOR E ESTAGIÁRIO}

RC: 88720

Disponível em: $\quad$ https://www.nucleodoconhecimento.com.br/educacao/percepcoes-da- 


\section{Percepção do Estágio Supervisionado do Professor Supervisor Alan}

A professora supervisora Bernardete afirmou que a sua relação com o estagiário Bruno foi orientada pela "reciprocidade, o respeito, a proatividade, o profissionalismo e o companheirismo" e considerou positivo o tempo com o estagiário Bruno.

A convivência e as trocas de experiências com o Bruno foram bastante enriquecedoras e pude analisar suas competências e qualidades de um bom profissional. Ele já está um profissional pronto, foi o melhor estagiário que já esteve comigo até hoje. Muito boa nossa relação em todos os aspectos (Entrevista Final).

A docente Bernardete acredita que exerce um importante papel no processo de formação profissional do estagiário: "Essa é a minha maior preocupação em contribuir na formação de futuros colegas de trabalho e me preocupo em prestar o melhor durante essa passagem de meu estagiário". E relatou se sentir capaz para tal, mas ainda ter dúvidas sobre o processo de orientação do estagiário. "Eu me sinto capaz, porém com dúvidas em relação por onde começar de qual ponto de partida. $\mathrm{Na}$ verdade, não tenho a receita do bolo, porém sei que juntos iremos compartilhar dúvidas, sugestões e criarmos um ambiente facilitador". A PS ainda acrescentou que acredita seja necessária uma capacitação específica para o professor supervisor para que este oriente outros futuros colegas de trabalho de forma verdadeiramente profícua: "Percebo sim o quanto é importante de verdade ter esse conhecimento (formação específica) (Entrevista Final).

\section{Percepção do Estágio Supervisionado da Estagiária Alice}

O estagiário Bruno comentou que sua relação com a professora supervisora Bernadete foi muito profícua e que ela demonstrou interesse em orientá-lo nos diversos momentos do estágio: "A minha relação com a Bernardete foi a melhor possível, ela me orientou muito bem, tudo que eu tinha dúvida ela tava sempre pronta para me ajudar, me deu dicas, entre outras coisas. Nossa comunicação era muito

RC: 88720

Disponível em: $\quad$ https://www.nucleodoconhecimento.com.br/educacao/percepcoes-daprofessora 
fluente". Ainda sobre o relacionamento com a professora supervisora, o estagiário esclareceu que eles estiveram em sintonia e que o estágio foi uma experiência positiva para ele: "A atuação (em parceria) foi a melhor possível, a gente atuou em sintonia e eu fiquei muito animado com relação ao estágio, como foi meu primeiro, foi uma experiência superlegal e estou ansioso, inclusive para passar novamente (Entrevista Final).

Ainda sobre a professora supervisora:

A minha orientadora local foi a peça que mais agregou nesse estágio. Uma excelente profissional que faz o que ama. Me recebeu muito bem, me orientou de forma majestosa e ela me tratava como se fosse professor. Dávamos aulas juntos, e ela me orientava no que acreditava que eu poderia melhorar ou sobre alguma situação especifica referente ao ambiente (Relatório Final)

O estagiário ainda acrescentou avaliando todo o processo de estágio dizendo que a experiência do estágio no ambiente que será seu futuro local de trabalho foi muito válida e que isso proporcionou rever alguns conhecimentos aprendidos nas disciplinas e aumentar sua segurança na escolha da profissão.

Após esse período no estágio, pude adquirir muito mais experiência no campo da docência. Estive com pessoas maravilhosas, num ambiente que exemplifica a realidade do ensino público que será uma das minhas possíveis áreas de trabalho. Pude por em prática conteúdos relacionados a diversas disciplinas que já cursei. Como primeiro estágio, tive uma visão muito positiva e que me trouxe uma segurança enorme sobre a minha decisão de carreira (Relatório Final).

\subsection{REFLEXÃO SOBRE A PRÁTICA DOCENTE NO COTIDIANO ESCOLAR}

\section{Percepção do Estágio Supervisionado do Professor Supervisor Alan}

RC: 88720

Disponível em: $\quad$ https://www.nucleodoconhecimento.com.br/educacao/percepcoes-da- 
Sobre o aprendizado do estagiário Bruno, a professora Bernardete esclareceu a importância do estagiário ter vivido o ambiente escolar e sua realidade.

Quando iniciamos o estágio acabei trazendo essa discussão a respeito das aulas de Educação Física devido a questões da falta de materiais, necessidades de melhores estruturas e espaços para as aulas de Educação Física, sobre a não importância das aulas de Educação Física de alguns alunos que se negam a fazer e ele também acabou vivenciando isto na prática (Entrevista Final).

A professora Bernardete acrescentou ser muito importante o estagiário aprender a considerar as diferentes situações que ocorrem à sua volta e que existem várias formas de agir, pensar e solucionar os problemas durante as aulas. A docente acrescentou que a sua intenção não era que o estagiário a imitasse ou repetisse qualquer comportamento, mas sim, de aprender a

manter uma postura profissional e acima de tudo o respeito. De transmitir as experiências e possibilitar toda uma interação baseada na construção do conhecimento por meio de um diálogo entre professor, aluno e propiciar um ambiente facilitador para a aprendizagem ocorrer normalmente (Entrevista Final).

Quando perguntada se teria algum último conselho ou sugestão para o estagiário Bruno, a professora disse: "Não desistir de sua profissão, pois teremos muitas adversidades durante o caminho da docência". (Entrevista Final).

\section{Percepção do Estágio Supervisionado da Estagiária Alice}

Para o estagiário Bruno, é mais importante aprender, no estágio, os mecanismos e técnicas de como dar aula do que sobre o cotidiano docente, visto que quando for professor efetivo de uma escola, aprenderá na prática:

Bom, eu acho que é mais importante aprender o que fazer na prática escolar porque o que a gente vai aprender no mundo do trabalho docente a gente só vai aprender quando a gente se formar, quando a gente tiver isso no dia a dia e nosso cotidiano. A gente vai ter prática

RC: 88720

Disponível em: $\quad$ https://www.nucleodoconhecimento.com.br/educacao/percepcoes-da- 
com tipos de escolas diferentes, tipos de instituições diferentes e isso vai trazer a experiência (Entrevista Final).

Quando perguntado sobre o aprendizado construído nesse período de estágio na escola B sob a supervisão da professora Bernadete, o estagiário comentou que:

Nossa...(risos), eu aprendi muita coisa, muita coisa porque eu nunca tinha dado aula para uma quantidade de crianças, naquele espaço público e naquela escassez de material, então eu aprendi a me virar com tudo aquilo, aprendi a me virar com diferentes tipos de personalidades das crianças e foi uma coisa que acrescentou muito (Entrevista Final).

\section{DISCUTINDO OS DADOS...}

A PS concebe o período do estágio curricular supervisionado como uma importante etapa da formação docente e se preocupa em estimular o estagiário com conversas e exemplos de sua própria trajetória. Para a professora, o estagiário deve conhecer todos os espaços escolares e vivenciar todas as problemáticas inerentes a uma escola pública da cidade.

Os professores em exercício são chamados a desempenhar o papel de iniciadores de uma nova geração docente, algo que lhes possibilita vivenciar novas aprendizagens, ao mesmo tempo que sentimentos de valorização de seus saberes e práticas profissionais (SARTI, 2009, p. 134).

A professora supervisora, mesmo sem muitas orientações, concluiu que ofereceu um acolhimento adequado ao estagiário, dotado de muita parceria e autonomia e que proporcionou a ele o máximo de acesso a realidade escolar, proporcionando vivência antecipada de uma escola de verdade. Ela relatou que entende a importância do estágio curricular supervisionado para a formação profissional e que participar da formação do estagiário é muito gratificante.

A legislação vigente no Brasil prioriza e normatiza o estágio colocando diretrizes para a parte cedente (universidade), concedente (escola);

RC: 88720

Disponível em: https://www.nucleodoconhecimento.com.br/educacao/percepcoes-da- 
carga horária, seguro saúde, direitos e deveres dos estagiários e o papel do professor (universidade), porém fica em aberto a questão do professor-colaborador (PC), bem como sua função (BENITES, 2012, p. 12).

A PS avaliou o processo de estágio de forma positiva e destacou que o estagiário foi proativo e de muita ajuda no controle das turmas e na aplicação das atividades.

$\mathrm{Na}$ escola, é importante destacar que a percepção da PS Bernardete sobre o acolhimento oferecido a seu estagiário é bem similar da percepção que ele teve desse período de formação. O estagiário Bruno acredita que teve na escola $B$ a oportunidade de fazer parte de uma unidade pública escolar e vivenciá-la de forma muito respeitosa e agregadora com todos os funcionários. Ele entende que a professora Bernardete teve papel importante nesse processo, pois foi ela quem o acolheu e orientou ao longo desse processo formativo, com estímulos à parceria e à autonomia.

O estagiário percebe que o período de estágio vivido foi muito profícuo e enriquecedor por ter tido a oportunidade de exercer a docência de forma ativa, com supervisão da PS, que the disponibilizou orientações e feedbacks sobre suas intervenções e na sua reflexão sobre ser professor.

Ao conversar com o estagiário Bruno, a percepção do estágio foi bem similar ao da PS, pois ele pontuou o interesse pelo estágio apresentado pela professora Bernardete, sempre muito presente nas aulas, proporcionando momentos destinados a orientação e feedbacks das intervenções realizadas e convite para participar de outros espaços e eventos escolares.

Além disso, comentou que mesmo com as diversas demandas problemáticas que a escola possuía, teve a oportunidade de vivenciar e aprender sobre o cotidiano de uma escola pública da cidade e que a PS contribuiu muito para sua formação profissional, sempre preocupada em apresentar e refletir sobre a realidade escolar.

RC: 88720

Disponível em: https://www.nucleodoconhecimento.com.br/educacao/percepcoes-daprofessora 


\section{CONSIDERAÇÕES FINAIS}

É importante para a formação profissional do futuro professor que haja uma parceria entre todos os envolvidos nesse processo de estágio, em destaque, para a universidade e a escola, dois fundamentais espaços de formação (SARTI, 2009).

No ambiente escolar, o professor supervisor é o participante que mais de destaca, pois tem o compromisso de receber, acolher e acompanhar o estagiário ao logo do período de estágio. Mas para o sucesso do estágio, o professor precisa entender seu papel de formador e querer participar da formação profissional do graduando. Além disso, é importante que o professor tenha a devida formação sobre como exercer esse papel de formador junto ao seu estagiário (BENITES, 2012).

Essa pesquisa demonstrou que o a professora Bernardete não possuía uma formação especial para orientar seu estagiário e, também, não recebeu capacitações da universidade que envia o estagiário a escola. Com isso, agiu da forma que entendeu ser a mais correta e acertada com sue estagiário, muitas vezes de forma insegura. $\mathrm{O}$ estagiário Bruno, percebeu essa deficiência da professora, mas acreditou ter tido um bom estágio por mérito da dedicação da professora.

Com isso, é importante ampliar o campo de discussão e reflexão sobre o estágio curricular supervisionado e a formação desses professores supervisores, com objetivo que tenham condições de escolherem posturas e condutas com seus estagiários de forma mais consciente.

\section{REFERÊNCIAS}

BARDIN, L. Análise de conteúdo. Lisboa: Edições 70, 1977.

RC: 88720

Disponível em: https://www.nucleodoconhecimento.com.br/educacao/percepcoes-daprofessora 
BENITES, L. O professor-colaborador no estágio curricular supervisionado em Educação Física: perfil, papel e potencialidades. 2012. 180 p. Tese - (doutorado) - Universidade Estadual Paulista, Instituto de Biociências de Rio Claro, 2012. DOI: http://dx.doi.org/10.18511/rbcm.v20i4.3286

BRASIL. Congresso Nacional. Lei11.788, de 25 de setembro de 2008. Dispõe sobre o estágio de estudantes; altera a redação do art. 428 da Consolidação das Leis do Trabalho - CLT, aprovada pelo Decreto-Lei № 5.452, de 1o de maio de 1943, e a Lei no 9.394, de 20 de dezembro de 1996; revoga as Leis nos 6.494, de 7 de dezembro de 1977, e 8.859, de 23 de março de 1994, o parágrafo único do art. 82 da Lei no 9.394, de 20 de dezembro de 1996, e o art. 6o da Medida Provisória no 2.164-41, de 24 de agosto de 2001; e dá outras providências.. Brasília, 25 set. 2008. Disponível em:< http://www.planalto.gov.br/ccivil_03/_ato2007-2010/2008/lei//11788.htm> Acesso em: 03 jan. 2018.

MOTA, D. Licenciandos de Educação Física no contexto do Estágio Curricular Supervisionado: um estudo sobre indicadores de acolhimento- Dissertação (Mestrado em Educação Física)- UNESP, Presidente Prudente, 2020. 176p.

PIMENTA, S.; LIMA, M. Estágio e docência. Ed. São Paulo: Cortez: São Paulo, 2011. SARTI, F. M. Parceria intergeracional e formação docente. Educação em Revista, Belo Horizonte, v. 25, n. 2, p. 133-152, 2009. DOI: https://doi.org/10.5216/rpp.v3i3e4.10

VEDOVATTO IZA, D. F.; SOUZA NETO, S. Por uma revolução na prática de ensino: o estágio curricular supervisionado. 1. ed. Curitiba, PR: CRV, 2015.

RC: 88720

Disponível em: $\quad$ https://www.nucleodoconhecimento.com.br/educacao/percepcoes-daprofessora 
AGRADECIMENTOS: À CAPES, pois o presente trabalho foi realizado com apoio da Coordenação de Aperfeiçoamento de Pessoal de Nível Superior - Brasil (CAPES) Código de Financiamento 001.

Enviado: Fevereiro, 2021.

Aprovado: Junho, 2021.

RC: 88720

Disponível em: https://www.nucleodoconhecimento.com.br/educacao/percepcoes-daprofessora 